\title{
РОЗУМІННЯ ПОНЯТТЯ «ОСОБИСТА СОЦІАЛЬНА ВІДПОВІДАЛЬНІСТЬ» МАЙБУТНІМИ СПЕЦІАЛІСТАМИ ФАРМАЦІї
}

\author{
(C) Н. О. Ткаченко
}

\section{Запорізький державний медичний університет}

\begin{abstract}
Резюме: у статті теоретично обґрунтовано фрормування соціальної відповідальності як професійної компетенції майбутніх фрахівців фрармації. Компетенція «соціальна відповідальність» виступає чинником перетворення отриманих профресійних знань та вмінь у систему поглядів на суспільне значення срармації, срармацевтичної організації, себе і свого місця у фармацевтичній системі.

Проведено аналіз розуміння поняття «особиста соціальна відповідальність» майбутніми спеціалістами фрармації та їх самооцінки себе як відповідальної особи.
\end{abstract}

Ключові слова: соціальна відповідальність, фрармація, особиста відповідальність, студенти.

Вступ. Сьогодні трансформація суспільних цінностей та пріоритетів вимагає внесення змін до практики менеджменту, забезпечення інтеграції принципів соціальної відповідальності (CВ) у діяльність фрармацевтичних підприємств і компаній. Різним аспектам впровадження основних засад концепції СВ у фрармацевтичну галузь присвячені роботи вітчизняних вчених А. А. Котвіцької, О.В.Посилкіної, Ю. С. Братішко, А. С. Немченко, Б. П. Громовика та ін. [1-4]. Проте мало уваги приділено питанням особистої соціальної відповідальності (ОСВ), їі ролі і місця в моделі СВ поведінки фармацевтичних організацій та професійній відповідальності фрахівців.

Актуальність проблеми зумовлена, з одного боку, зростаючою активністю СВ фрахівця, необхідністю подання ним відповідальності як смислової сутності системи цінностей і ціннісних орієнтирів, а також регуляторів суспільних відносин сучасного українського суспільства. 3 іншого боку, у зв'язку з модернізацією української вищої освіти змінюється основний зміст навчально-виховної діяльності у системі вищої фрармацевтичної освіти. Вона впевнено переорієнтувалася на фрормування профресійних компетенцій, які $€$ показниками якості підготовки фрахівців та визначають їх поведінкові характеристики на ринку праці. Для умов діяльності сучасного спеціаліста фрармації, крім професійних знань та вмінь, нині необхідні СВ та інтелектуальна чесність, розвинений гуманістичний світогляд.

СВ має складну ієрархічну структуру, головна роль в якій належить особистісному рівню, де людина виступає суб'єктом конкретної діяльності. Переважання типу поведінки, де задіяна воля особистості, і зумовлює рівень її СВ. Сутність ОСВ суб'єктами фрармації сьогодні трактується по-різному і це є проблемою визначення її як поняття, методики її оцінки та системи іiі фрормування [5,6]. Останнім часом з'являється все більше наукових праць з формування СВ у фахівців різних галузей, однак проблема формування компетенцій провізора у контексті СВ фрармацевтичних організацій поки що не отримала належного теоретичного обґрунтування і практичного вирішення.

Метою роботи стало вивчення сутності ОСВ в рамках фрармацевтичної діяльності та виявлення рівня повноти і розуміння суті цього поняття майбутніми спеціалістами орармації.

Методи дослідження. Для досягнення мети необхідно було узагальнити існуючий науковий матеріал, уточнити і поповнити понятійний апарат з визначеної тематики, доопрацювати існуючий теоретичний досвід. Крім того, провести опитування майбутніх спеціалістів фрармації щодо розуміння ОСВ та визначити його рівень.

В якості матеріалів дослідження використано результати фрундаментальних і прикладних досліджень вітчизняних і зарубіжних фрахівців із зазначеного вище питання. Для другої частини дослідження були обрані студенти-випускники фрармацевтичного фракультету Запорізького державного медичного університету заочної фрорми навчання (ЗФН). Основними критеріями у виборі респондентів стали практичний досвід та віковий показник.

Ми використовували такі методи досліджень: аналізу та синтезу, логічного пізнання, порівняння, узагальнення, контент-аналіз та анкетування. Проанкетовано 167 студентів 5 та 6 курсів за спеціальністю «Фармація». Анкетування здійснювалось протягом січня 2015 року.

Результати й обговорення. Нове розуміння вищої фрармацевтичної освіти в контексті компетентнісного підходу передбачає інтеграцію становлення компетентного фрахівця з фрормуванням його як соціально

ISSN 2312-0967. Фармацевтичний часопис. 2015. № 3 
відповідальної особистості, що відображено в нових вимогах до випускників фрармацевтичних вузів.

Тривалий час проблему відповідальності досліджували здебільшого юристи [7]. Однак діапазон поглядів на сутність цього питання поступово розширювався: відповідальність почали розглядати як морально-етичну категорію, а пізніше - як один із елементів комплексної навчально-виховної системи.

Особливо цінний внесок у розуміння відповідальності як моральної категорії, її ролі в становленні особистості зробив В. Сухомлинський. Поєднуючи три найважливіші людські якості (громадянськість, відповідальність і совість), він виділяв їх специфічну ознаку, яка характеризує здатність особистості самостійно обирати моральні обов'язки, вимагаючи від себе їх виконання, здійснюючи самооцінку та самоконтроль [8].

На основі аналізу наукової літератури доведено, що відповідальність $€$ інтегрованим комплексом якостей особистості, що визначають ії соціальну спрямованість, зумовлюють здатність до соціально значущої та індивідуально необхідної діяльності відповідно до існуючих морально-правових нормам.

У зв'язку з цим посилюється значення психологопедагогічних та професійних морально-етичних знань, умінь, навичок спеціаліста фрармації як передумови успішного здійснення ним професійної діяльності. У свою чергу, ефективне формування таких знань, умінь і навичок, особистісних якостей майбутнього фрахівця потребує посилення навчальновиховного процесу, загальнонаукової, спеціальної й профресійної етичної підготовки в фрармацевтичних $\mathrm{BH} 3$.

Спеціаліст починається 3 особистості. Профресіоналізм майбутнього провізора залежить від його особистісних характеристик: чесності, активності, сумлінності, тому потрібен індивідуальний підхід до кожного. Формування особистості майбутнього фрахівця фрармації відбувається в певному соціальному середовищі (студенти, ВН3, фрармацевтичні організації), яке створює умови для самовдосконалення в напрямі обраної профресії. Відповідальність, дисципліна, колективізм, гуманізм і свідоме служіння суспільству повинні бути сорормовані в процесі профресійної підготовки. Висока культура людського спілкування, толерантні міжособистісні відносини, незалежно від національних, консеесійних та інших відмінностей, також повинні фоормуватися в процесі професійної підготовки спеціаліста орармації.

Розвиток відповідальності як особистісної якості відбувається завдяки самоконтролю, внаслідок чого особистість перетворюється 3 простого виконавця зовнішніх норм і розпоряджень на активного й творчого суб'єкта діяльності. За таких умов фрахівець свідомо обирає напрям особисто значущої й водночас соціально відповідальної поведінки. Зовнішні норми, що регламентують його поведінку, переходять у внутріш- ні регулятори, коли вже сама особистість визначає норми поведінки, масштаби своїх дій і відчуває відповідальність за їх результати. На основі знань про соціальні норми й правила поведінки, позитивного емоційного ставлення до них відбувається фрормування операційної сторони відповідальності - здатність діяти відповідально й ефективно [9].

Для уточнення, що саме студенти вкладають у поняття «ОСВ» та повноту його змісту, нами було запропоновано 9 характеристик особистої соціально відповідальної поведінки фрахівця фрармації з можливістю сфрормулювати інші характеристики на розсуд респондентів. Перелік складових ОСВ сорормовано за допомогою контент-аналізу наукової літератури.

Стосовно характеристики респондентів можна відмітити, що основну їх частину, складають особи у віці 20-25 років - 71,3 \%. Майже $20 \%$ від усіх опитаних - це студенти від 26 до 30 років. Тільки $6 \%$ склали особи віком 31-35 років. Незначну частину - 4,8 \% респонденти понад 35 років.

Вивчаючи попередній освітній рівень респондентів, з'ясовано, що більшість - це студенти, які мають професійну освіту рівня «молодший спеціаліст» $64 \%$. Тільки повну загальну середню освіту - $21 \%$; після медичного училища (коледжу) - 11,4 \% студентів. Найменшу частку респондентів склали студенти, які вже мали іншу вищу освіту - 3,6 \%. Серед них такі особи, як біологи, фрілологи, інженери, будівельники (рис. 1).

Для зручності обробки результатів, відповіді респондентів умовно поділили на п'ять груп. Група А визначалась показниками обирання студентами характеристики від 100 до 80 \% ; група В - від $79 \%$ до 60 \%; група С - від 59 \% до 40 \%; група D - від 39 до $20 \%$ та група Е - нижче $20 \%$ (рис. 2).

Аналіз відповідей показав, що до групи A та групи $E$ не увійшло жодної із характеристик ОСВ, тобто більшість студентів на сьогодні не мають сформованої одностайної думки щодо прояву спеціалістом фрармації ОСВ.

До групи В належить лише одна характеристика, яка найчастіше обиралася студентами. На думки $66,47 \%$ опитаних ОСВ - це, насамперед, готовність відповідати за свої дії.

Група C нараховує найбільшу кількість характеристик ОСВ. Увійшло 6 варіантів відповідей, що визначають ОСВ як: передбачення наслідків вибору, рішень, дій; готовність і бажання вибирати й приймати рішення; прагнення до самореалізації у об'єктивному світі; усвідомлення необхідності діяти у відповідності з суспільними вимогами і нормами як соціальними цінностями; усвідомлення своєї соціальної цінності та суспільної ролі; критичність і постійний контроль за своїми діями, урахування їх наслідків для людей.

Група D визначилась варіантами відповідей студентів таких, як «соціально відповідальна діяльність» та «самооцінка і само звітування».

ISSN 2312-0967. Pharmaceutical review. 2015. № 3 
Фармацевтична освіта

Pharmaceutical education

$$
\begin{aligned}
& \text { по } 20 \text { років } \quad \text { 20-25 років } \\
& \square \text { 26-30 років } \quad \text { 31-35 років } \\
& \square \text { старше } 35 \text { років }
\end{aligned}
$$

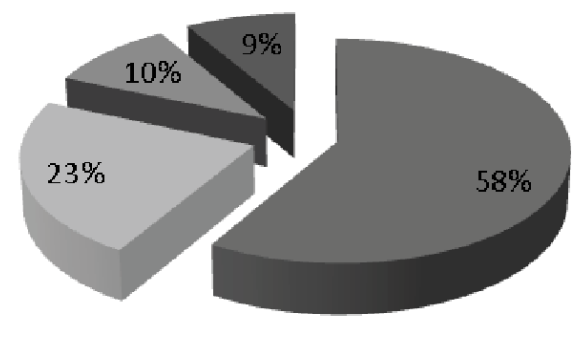

друга вища освіта

вагальна середняя освіта

ш молодший спеціаліст (фармація і медицина)

ш молодщший спеціаліст (медицина)

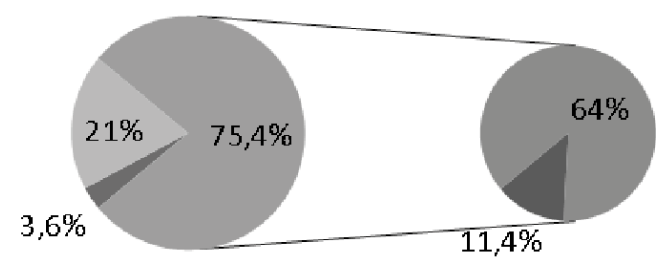

Рис. 1. Діаграми розподілу респондентів за віком та рівнем освіти.

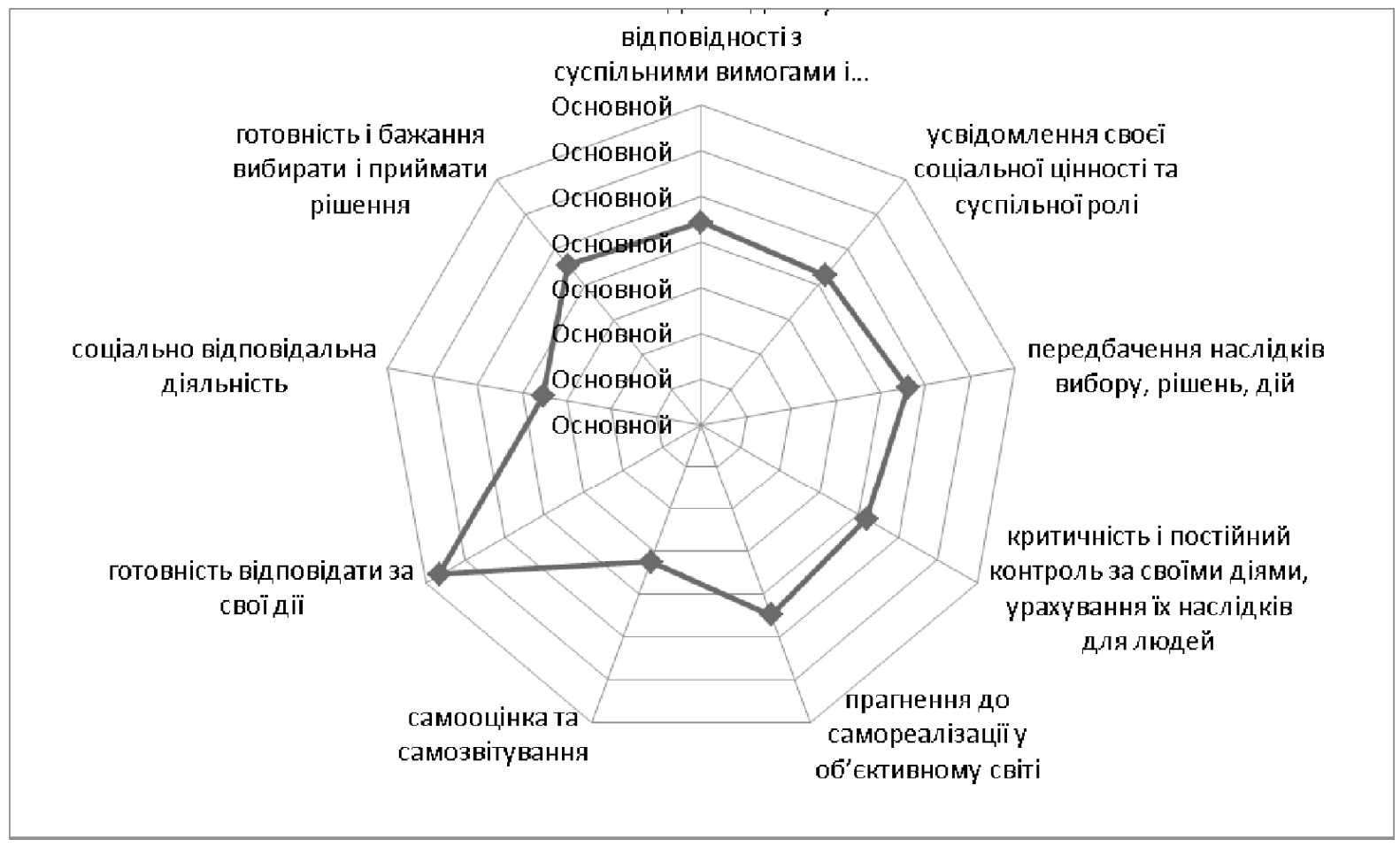

Рис. 2. Діаграма розподілу відповідей респондентів стосовно характеристики ОСВ.

При визначенні повноти змісту поняття «ОСВ» враховували кількість обраних студентом складових ОСВ при відповіді із 9 запропонованих варіантів у анкеті.

Встановлено, що тільки 8,38 \% опитаних (14 студентів) обрали усі 9 характеристик ОСВ (рис. 3). Найчастіше - 17,96 \% (30 респондентів) - студенти оби- рали по 4 характеристики переліку; 16,77 \% (28) - по 3 характеристики; 12,57 \% (21) - по 5 характеристик OCB.

Необхідно відмітити, що 17,96 \% опитаних вибирали лише одну характеристику із 9 запропонованих: «усвідомлення необхідності діяти відповідно до суспільних вимог і норм як соціальних цінностей», або

ISSN 2312-0967. Фармацевтичний часопис. 2015. № 3 
Фармацевтична освіта Pharmaceutical education

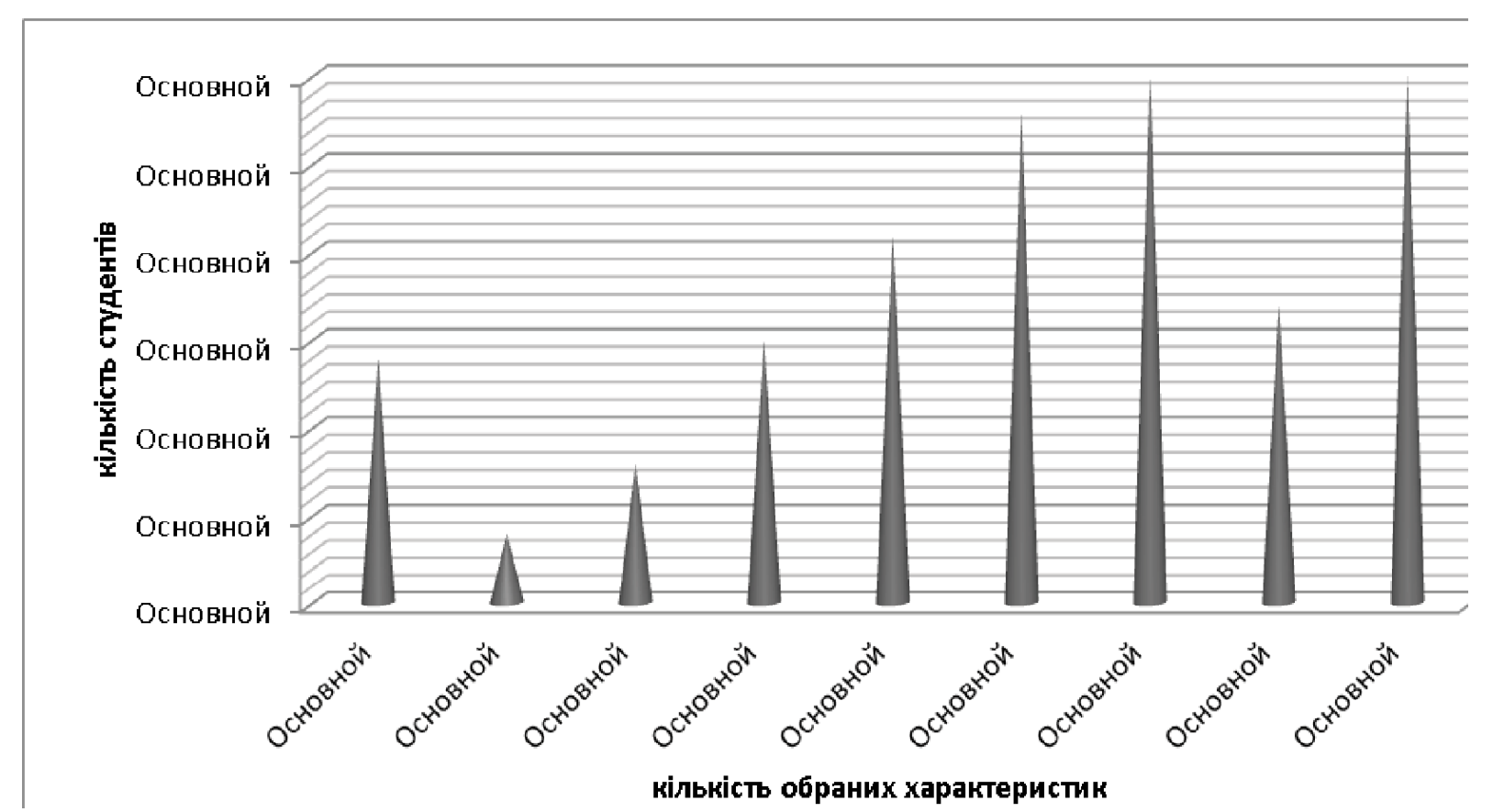

Рис. 3. Діаграма кількості обраних із переліку характеристик ОСВ.

«готовність відповідати за свої дії», або «усвідомлення своєї соціальної цінності та суспільної ролі».

Також, у ході опитування респондентам було запропоновано оцінити свою особисту відповідальність за допомогою загальних оцінок та окремих параметрів. Це досить важливий та актуальний момент самооцінки, адже відповідальність перед кимось починається, насамперед, з себе і оцінки своїх вчинків.

Як «відповідальна людина» себе оцінили майже 62 \% опитаних студентів. Характеризували себе як «відповідальна людина, але не завжди» $36 \%$ респондентів. Тільки 2 \% студентів вказали, що вони є «не дуже відповідальними». Характеристика себе за окремими параметрами особистої відповідальності відображена у таблиці 1.

Результати анкетування свідчать, що більшість студентів «часто» дотримуються запланованого та доводять розпочату справу до кінця. Позитивним моментом $€$ те, що саме ця більшість «завжди» якісно виконує свою роботу.

На жаль, тільки 29,4 \% майбутніх фрахівців «завжди» планують і дотримуються намічений дій і усього лише 44,31 \% - доводять почату справу до кінця.

Отримані результати самооцінки свідчить про досить високий рівень організаційно-виконавський здібностей та самосвідомості майбутнього покоління фрахівців фрармації. Однак, враховуючи попередні результати розуміння студентами поняття «ОСВ» й повноту його змісту, можна сумніватися в об'єктивності такої самооцінки та її диспропорції з фрактичним станом речей.

Висновки. 1. Функції профресійної освітньої системи прямо пов'язані з моделюванням та вихованням соціально відповідальної поведінки фрахівців фрармації, що в майбутньому має створити фундамент соціально відповідальних дій організацій фрармацевтичної галузі. Ефрективність навчання і виховання майбутніх провізорів значно підвищується в тому випадку, коли орормування ОСВ визнається обов'язковим компонентом їхньої професійної підготовки.

Проведені дослідження виявили, що більшість майбутніх спеціалістів знайома з поняттям ОСВ, але повнота його визначення досить різниться. Студенти випускних курсів ЗФН не мають одностайної думки щодо прояву СВ фрармацевтичним працівником. Виявлена істотна роз'єднаність у вихідних десрініціях терміна ОСВ потребує розробки моделі формування СВ студентів ВН3 фрармацевтичного спрямування та єдиного підходу у викладанні окремих тем організаційно-управлінських дисциплін.

Таблиця 1. Оцінка особистої відповідальності студентами-випускниками ЗФН

\begin{tabular}{|c|c|c|c|c|c|}
\hline & & Заво 3/п & Часто & 3рідка & Іноді \\
\hline 1 & Дотримуюсь запланованого & $29,4 \%$ & $63 \%$ & $4,2 \%$ & $2,4 \%$ \\
\hline 2 & Доводжу почату справу до кінця & $44,31 \%$ & $50,3 \%$ & $3,59 \%$ & $1,8 \%$ \\
\hline 3 & Якісно виконую роботу & $56,29 \%$ & $41,31 \%$ & $1,2 \%$ & $1,2 \%$ \\
\hline
\end{tabular}

ISSN 2312-0967. Pharmaceutical review. 2015. № 3 


\section{Список літератури}

1. Соціальна фрармація в Україні : стан, проблеми та перспективи : матер. всеукр. наук.-практ. інтернетконфреренції за участю міжнародних спеціалістів, 3 квітня 2013 р. / ред. кол. : А. А. Котвіцька та ін. - Х. : Вид-во НфраУ, 2013. - 350 с.

2. Соціальна фрармація в Україні : стан, проблеми та перспективи : матер. всеукр. наук.-практ. інтернетконореренції, 17-20 березня 2014 р. / ред. кол. : А. А. Котвіцька та ін. - Х. : Вид-во НораУ, 2014. - 488 с. 3. Соціальна фрармація : стан, проблеми та перспективи : міжн. наук.-практ. інтернет-конореренції, 27-30 квітня 2015 р. / ред. кол. : А. А. Котвіцька та ін. Х. : Вид-во НфаУ, 2015. - 325 с.

4. Громовик Б. П. Ролі аптечних фрахівців з погляду соціальної фрармації / Б. П. Громовик, Л. М. Унгурян // Актуальні питання фрармацевтичної і медичної науки та практики. - 2013. - № 3. - С. 126-128.

5. Ткаченко Н. О. Теоретико-методологічні аспекти формування комунітарної соціальної відповідальності у фрармації / Н. О. Ткаченко, Л. М. Унгурян, Б. П. Громовик // Одеський медичний журнал. - 2014. - № 5. - С. 34-38.
6. Ткаченако Н. О. Соціальна відповідальність фрахівців фрармації як базовий елемент соціально відповідальної поведінки фрармацевтичних організацій / Н. О. Ткаченко, Б. П. Громовик, Є. Г. Книш // «Управління якістю в фрармації» : матеріали IX Науково-практичної консреренції (22 травня 2015 р., м. Харків) - Х. : Вид-во НФаУ, 2015. - С. 127-128.

7. Зайчук О. В. Теорія держави і права [Електронний ресурс] : академічний курс, підручник / О. В. Зайчук, Н. М. Оніщенко. - К. : Юрінком Інтер, 2006. - Режим доступу : http://www.ebk.net.ua/Book/law/zaychuk_tdp/ part3/2401.htm. Збірник наукових праць Полтавського державного педагогічного університету ім. В. Г. Короленка. - Випуск 5 (44). - Полтава, 2005. - Серія "Педагогічні науки". - 430 с.

8. Голова Н. І. Виховання відповідальності у старшокласників у процесі учнівського самоврядування : авторефр. дис. ... канд. пед. наук. : спец. 13.00.07 - теорія і методика виховання / Н. І. Голова; Хмельницький національний університет. - Хмельницький : Вид-во XНУ, 2010. - 15 c.

\section{ПОНИМАНИЕ ПОНЯТИЯ «ЛИЧНАЯ СОЦИАЛЬНАЯ ОТВЕТСТВЕННОСТЬ» БУДУЩИМИ СПЕЦИАЛИСТАМИ ФАРМАЦИИ}

\section{Н. А. Ткаченко}

Запорожский государственный медицинский университет

Резюме: в статье теоретически обосновано формирование социальной ответственности как профессиональной компетенции будущих специалистов фрармации. Компетенция «социальная ответственность» выступает фрактором преобразования полученных профессиональных знаний и умений в систему взглядов на общественное значение фрармации, фрармацевтической организации, себя и своего места в фрармацевтической системе.

Проведен анализ понимания «личная социальная ответственность» будущими специалистами фрармации и их самооценки себя как ответственного лица.

Ключевые слова: социальная ответственность, фрармация, личная ответственность, студенты.

\section{UNDERSTANDING OF THE CONCEPT "PERSONAL SOCIAL RESPONSIBILITY" BY THE FUTURE SPECIALISTS IN PHARMACY}

\section{N. O. Tkachenko}

\section{Zaporizhian State Medical University, Zaporizhzhia, Ukraine}

Summary: the article adduces the theoretically grounds of formation of social responsibility as a professional competence by the future specialists in pharmacy. The competence of the "social responsibility" is a factor converting the obtained professional knowledge and skills in system of views on social value of pharmacy, pharmaceutical organizations, one and one's place in the pharmaceutical system.

There was analyzed the understanding of "personal social responsibility" by future specialists of pharmacy and their selfesteem by themselves as a responsible person.

Key words: social responsibility, pharmacy, personal responsibility, students.

Отримано 13.05.2015

ISSN 2312-0967. Фармацевтичний часопис. 2015. № 3 